\title{
Dividends, Net Income After Taxes and Earnings Per Share and Their Impact on the Market Capitalization of Listed Companies Amman Stock Exchange During the Period 1978-2016
}

\author{
Ateyah Alawneh ${ }^{1}$ \\ ${ }^{1}$ College of Business, Tafila Technical University, Jordan \\ Correspondence: Ateyah Alawneh, College of Business, Tafila Technical University, Jordan. E-mail: \\ ateayh1@yahoo.com
}

Received: August 15, 2018

Accepted: September 14, $2018 \quad$ Online Published: September 25, 2018

doi:10.5539/ijef.v10n10p69

URL: https://doi.org/10.5539/ijef.v10n10p69

\begin{abstract}
The study aims to measure the impact of dividends, net income after taxes and earring per share on the market capitalization of companies listed in Amman Stock Exchange during the period 1978-2016. The study using E-views program to analyze the data, as the analysis showed that there is statistically significant positive relationship between the dividends and the market capitalization. As well as, a positive relationship between the net income after taxes and the market capitalization of listed companies in Amman Stock Exchange. The study found that there is no statistically significant between earnings per share and market capitalization, and this means that investors are interested in dividends and net income after taxes in the demand on shares, but they do not care about earnings per share when they demand shares.
\end{abstract}

Keywords: dividends, net income after taxes, earnings per share

\section{Introduction}

Dividends, net income after taxes and earnings per share are important financial indicators for investors; to demand the company's shares. The investor looks forward to dividends of companies, net income after taxes and earnings per share; because they are important factors which affect the share price. Furthermore, the financial management of companies concern about the policy Dividends; by retaining a certain amount of funds to finance investments. It is necessary to determine the retained amount and the distributed amount; because of their impact on the market capitalization of companies. Therefore, various recent studies have paid attention to these factors and their impact on market capitalization. However, this study concerns on some of the fundamental factors which affect the market capitalization, and which decision makers found that they affect the share's market capitalization. Also, the study investigated the causal relationship between these factors, the correlation between them, their evolution and the degree of stability of each of these factors during the years of study.

\subsection{The Problem of the Study}

The Problem of the study is to determine the impact of dividends, net income after taxes and earring per share on the market capitalization of companies listed in Amman Stock Exchange. Do these factors affect the market capitalization? Are the corporate managers and shareholder highly interested in the market capitalization of the stock?

The agents of the companies (managers) aim to maximize the market capitalization of the company's shares; which lead to maximize the wealth of owners or shareholders. Shareholders ask the management to raise the market capitalization of the company's shares; to earn capital gains(Market Capitalization more than nominal value).Furthermore, the management's efficiency is measured by its ability to raise the market capitalization of the company, which is a result and summary of good management performance for the past financial period. Therefore, the problem of the study is to investigate the main factors that affect the market capitalization of shares listed in Amman Stock Exchange; by formulating the problem of the study with the following questions:

* What is the impact of dividends on the market capitalization of companies listed in Amman Stock Exchange?

* What is the impact of net income after taxes on the market capitalization of companies listed in Amman 


\section{Stock Exchange?}

* What is the impact of earnings per share on the market capitalization of companies listed in Amman Stock Exchange?

\subsection{The Objectives of the Study}

The study objectives are derived from the independent variables, which have a direct impact on the market capitalization of companies listed on Amman Stock Exchange, and they can be summed up in the following:

* A statement of the variables' evolution during the study period (market capitalization, dividends, net income after taxes and earnings per share) of companies listed in Amman Stock Exchange.

* Estimation of the independent variables' impact(dividends, net income after taxesand earnings per share) on the market capitalization of companies listed in Amman Stock Exchange.

* The strength of the correlative relationship between the independent and dependent variables.

* Studying the degree of the study variables' stability.

* Study the causal relationship between the variables of the study.

* Make recommendations that help decision makers in companies and investors in the shares of companies.

\subsection{The Importance of the Study}

The importance of the study stems from the increasing interest in the factors that impact the market value, especially among the company managers, the owners of the company and the investors in the shares. Whereby, the factors have a significant impact on the ability of companies, and evaluate the efficiency of their performance, which is reflected on the value of the stock market; because the ultimate goal of financial management in the company is to raise the value of the stock in the market, which assesses the company and its manger during the past period. So, the study of this subject is very important for companies to determine the factors affecting the value of the stock in the market, which is the most important factor for the investors, also any factors taken into consideration by the investor and investment decision makers.

\subsection{The Study Hypotheses}

The study is based on the following assumptions

* There is a statistically significant positive relationship at the level of $(\alpha \geq 0.05)$ between the dividends and the market capitalization of companies listed in Amman Stock Exchange.

* There is a statistically significant positive relationship at the level of $(\alpha \geq 0.05)$ between the net income after taxes and the market capitalization of companies listed in Amman Stock Exchange.

* There is a statistically significant positive relationship at the level of $(\alpha \geq 0.05)$ between the earnings per share and the market capitalization of companies listed in Amman Stock Exchange.

\subsection{Study Model}

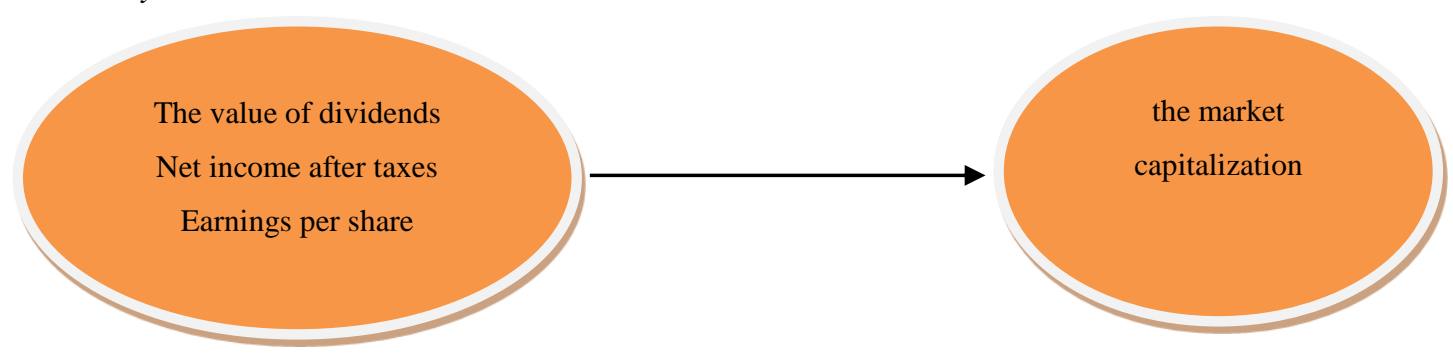

\subsection{Regression Method}

The study will rely on multiple linear regression methods, and the used program is (E-views) program, to study the impact of the independent variables on the market capitalization of companies listed in Amman Stock Exchange, where the following equation was used:

$$
=\mathrm{f}(\mathrm{DIV}, \mathrm{NI}, \mathrm{EPS}, \mathrm{MC})
$$

Where:

* MC: the market capitalization of listed companies Amman Stock Exchange during the study period per Million Jordanian Dinars (JD). 
* DIV: The value of dividends for listed companies in Amman Stock Exchange per Million Jordanian Dinars (JD).

* NI: Net income after taxes to listed companies in Amman Stock Exchange/ Million Jordanian Dinars (JD).

* EPS: Earnings per share for listed companies in Amman Stock Exchange/ Million Jordanian Dinars (JD).

Accordingly, the multiple regression equation can be written according to the following formula:

$$
\mathrm{MC}=\mathrm{a}+\mathrm{B} 1 \mathrm{DIV}+\mathrm{B} 2 \mathrm{NI}+\mathrm{B} 3 \mathrm{EPS}+\mathrm{E} .
$$

Where B1, B2, B3, are the regression parameters for independent variables, which can be through their signals determines the direction of the relationship between the independent variables and the dependent variable.

\subsection{The Study Sources}

- Books, periodicals and research,

- Amman Financial Market Website to get data for variables.

\subsection{Study Methodology}

- Descriptive and inductive inferences Method;

- Quantitative Analysis Method.

\section{Literature Review}

* Study of Emeni and Ogbulu (2015)

The study aims to measure the impact of the dividend policy on the market capitalization of companies in the services sector in Nigeria. The study used statistical analysis using the method of (OLS), and the results of the study showed that the policy of distributing cash profits has a negative relationship with market capitalization, but not statistically significant for companies in the financial services sector. The most important recommendation is that companies operating in the financial services sector in Nigeria do not rely on dividend policy as a strategy to increase market value.

* Study of Kehinde, Uwalomwa, Olubukola, and Osariemen (2017)

The study aims to evaluate the policy of dividends and share price in Nigerian banks. The study used data from four major banks. The study used statistical analysis using the method of (OLS). The results of the study showed a positive relationship between earnings per share and Market Capitalization. The main recommendation of the study is to find effective policies to obtain more benefits from earnings per share for better performance.

* Study of Ashamu, James, and Abiola

The study aims to estimate the impact of dividend policies on corporate value. There are three important decisions; investment, funding decisions and allocation of profits. The study works to collect these decisions in order to achieve the goals required for companies; to maximize the wealth of shareholders. In order to reach the results, the study used the (SPSS) program. The statistical analysis of the study showed that changes in the policy of dividend lead to a large extent changes in the value of the company.

- Study of Vinay and Kavidayal (2015)

The study is trying to analyze the impact of dividends policies on the wealth of shareholders in Indian banks listed in Bombay Stock Exchange. The study used multiple regression methods, t-test, adjusted(R2) and (F-test). The results of the analysis revealed that there is a significant impact of the policy of dividend on the share price in Indian banks.

* Samuel, Duncan, and Lilian (2013)

The study aims at clarifying the impact of the dividends policy on the market capitalization of the banking industry in Kenya. The study used Pearson correlation analysis. The analysis showed a strong correlation between earnings per share, market value, profit growth and dividend policy. The main recommendation of the study is to allow the management of banks and the national bank of Kenya specifically to adjust dividends policy gradually with the needs of shareholders; in order to improve the market capitalization of shares.

* Study of Jalloh (2017)

The study aims to show the impact of earnings per share on the wealth of the shareholders in Nigeria among the agricultural sector. The statistical analysis of the study showed a positive correlation between (EPS) and corporate shareholders. The most important recommendations of the study were that companies, especially those 
operating in emerging industries such as agriculture, should ensure that they have good and strong dividend policies; in order to enhance their profitability and attract investments to the sector.

* Study of Yuga (2014)

The study examines the share price determinants of commercial banks listed in the Nepal Stock Exchange during the period 2006-2014.The study used multiple linear regression analysis. The results showed that earnings per share and price-earnings ratio had a statistically significant positive correlation with the share price, while dividends were inversely correlated with the share price.

* Study of Cristiano, Fernanda, and Denis (2013)

The study aims at searching for the factors influencing the cash distribution policies for the public companies listed in Brazil Stock Exchange. The statistical analysis of the study showed that the size of the company, profitability, market value, liquidity and profit growth have a strong relationship with the distribution policy to shareholders.

\section{* Studyof Rajesh and Sujit (2018)}

The study aims at understanding the determinants of profits for Indian companies. The study sample is 31234 companies representing 15 sectors of different industries, which represent the most intensive sectors in India. The results show that the higher the profit, the higher the tendency to pay dividends to shareholders. The study also shows that high-growth companies have a low distribution policy, while high-liquidity companies tend to dividends to shareholders.

\section{* Study of Amalia and Isrochmani (2014)}

The study aims to show the effect of net income after taxes, price to book value and debt to equity ratio on stock return in India. The study used data from the financial market for companies. The statistical analysis showed a statistically significant positive impact of both the net income after taxes and debt equity ratio on the stocks return, while the price to book value has a significantly negative relationship on the stocks return.

\section{* Study of Parviz and Abolghasem (2012)}

The study aims at verifying the impact of the assets return's rate on the prices of companies' shares in Tehran Stock Exchange. The statistical analysis of the study data showed a strong effect between the return of assets and shares of companies.

* Study of Pankaj (2017).

The study aims to clarify the effect of (EPS) and price earnings ratios on the market price of share. The study sample was 8 companies for the automotive sector. The study used the multiple regression model. The analysis showed there is a strong correlation between profit per share and stock market price, also there is a strong correlation between price earnings ratio and market price of share for the selected sample.

* Study of Thomas (2016)

The study aims to examine the most influential financial ratios on the share price of the industry and services sector. The study sample is 12 financial ratios. The study used (Stepwise) method for the analysis. The analysis showed that ROA, ROE and the net price ratio were the most influential on the share price of the industrial sector, while ROA, ROE, P / E and EPS have the most impact on the market price of the services sector.

* Study of Snežana and Ivan (2017)

The study aims at showing the effect of internal variables on the companies such as size of company, return on assets, return on shareholders' equity, earnings per share, book value, price to profit ratio, price to book value ratio, and the financial leverage on the share price. The results show that the variables; size of the company (measured by assets), return on assets, financial leverage, profit per share, book value, and price to book value ratio are statistically significant to the market price.

\subsection{What Distinguishes This Study}

This study differs from earlier studies in the following ways:

First: Most of the studies focused on the factors influencing the stock price of certain companies, while this study will take all companies listed in the Jordanian financial market.

Second: Most of the related studies had focused on the factors affecting the share price, while this study focused on the fundamental factors affecting the share price of all companies listed in Amman Stock Exchange. 
Third: This study will take into consideration the causal relationship between the variables and the degree of stability of the study variables(unit root) using the program (E-views).

\section{The Theoretical Framework of the Study}

Dividends, net profit, Earnings per share, market capitalization of the share, its concept and development during the study period.

\subsection{The Concept of Study Variables}

Dividends: are the returns made by the company during one financial period or during the period of the project, and which are due to shareholders or those who hold shares in the company's capital. Where the dividend is defined as the cash payments to be distributed to ordinary shareholders in accordance with the profitability and liquidity of the company (Hind, 2015). Companies follow different policies for the distribution of profits realized at the end of the financial year and hold the remaining portion of profits, and for distribution in the case of profits' decline. In general, it is possible to refer to the relationship between dividends and share price. As follows:

* The theory of Modigliani and Miller (1961): states that shareholders do not care about receipt of profits or not; because in the latter case, high profits must reflect the price of the stock; because the profits can be reinvested in shares, or alternatively some shares can be sold in cash, (Michelle, 2016).

* Gordon's theory (bird by hand): This theory assumes that dividends affect market value, where investors are working in the uncertainty of discounting distributions that occur after a long period of discount rate , which is higher than those that occur after a short period; because investor behavior is rational.

* Theory of the impact of information content or (reference) to the distribution of profits to investors: The theory assumes that investors look at distributions as a sign of company profit, whenever the higher the dividend, the higher the price and vice versa.

* The effect of the dividend policy on the total investors in the shares of the company.

Some investors prefer a high proportion of distributions as current income, and some prefer to hold profits and reinvest them. Accordingly, shareholders who prefer current income will buy shares of this kind, while those who prefer to hold higher profits will buy shares of the second type. Therefore, both cases affect the rise and fall of the company's shares(Amjad, 2009).

\subsection{Market Capitalization and Net Profit after Taxes}

Market Capitalization: The price of the stock during trading in the financial markets (the stock exchange). This value is highly volatile when compared to nominal value. The market capitalization changes depending on the company's financial position, net profit after taxes, dividends and earrings (Shukairy et al., 2016). Which will be the focus of this study. While it may be affected by the economic conditions or supply and demand for the company's shares, which has been highlighted in some previous studies. The market capitalization is affected by net income after taxes, which is permanent and indicates the effectiveness of managing the funds when investors expect an increase in net income after taxes, they buy shares. Therefore, the relationship is strong between net income after taxes and market capitalization with the stability of other factors; except factors that the company cannot control (Hind).

\subsection{Earnings Per Share and Net Income/Total Shares Outstanding (Stephen, Randolph, \& Brad, 2010)}

Some studies indicated the positive relationship between earnings per share and the share price in the market among some sectors; such as (Thomas, 2016) study of the services sector.

\subsection{The Development of Dividends, Net Income after Taxes, Earnings Per Share and Market Capitalization}

Table 1 shows that the variables of the study witnessed a remarkable development during the years of study, except for the earnings per share. Where the profits distributed by $(10,664,676)$, net profit after tax $(26,463,124)$ and market capitalization $(286,118,483)$ at the beginning of the study in 1978 . And continuously rose to $(755,840,798)$, $(829,157,424),(17,339,384,851)$ respectively by the end of the study in 2016 . While earnings per share fluctuated during the study years.

From the Figure 1, MC (market capitalization), dividend (DIV) and net income after taxes (NI) increase at the same level and trend, while earnings per share did not rise during the years of study; this means that there is a relationship between dividend, net income after taxes and market capitalization, except for earnings per share. Also table 5 shows the strength of the relationship between dividend, net income after taxes and market capitalization, while showed a weak relationship between earnings per share and market capitalization. This means 
that investors do not care about the earnings per share, while they are concerned about the dividends and net income after taxes of listed companies in Amman Stock Exchange.

Table 1. The development of dividends, net income after taxes, earnings per share and market capitalization

\begin{tabular}{|c|c|c|c|c|}
\hline Years & Dividends (JD) & Net income after taxes (JD) & Market Capitalization (JD) & (Earning per shear )EPS (JD) \\
\hline 1978 & $10,664,676$ & $26,463,124$ & $286,118,483$ & 0.317 \\
\hline 1979 & $14,743,936$ & $36,519,766$ & $452,291,527$ & 0.308 \\
\hline 1980 & $18,375,207$ & $44,494,224$ & $495,526,486$ & 0.358 \\
\hline 1981 & $22,616,688$ & $52,826,784$ & $834,614,580$ & 0.361 \\
\hline 1982 & $29,246,934$ & $60,769,009$ & $1,034,818,001$ & 0.223 \\
\hline 1983 & $27,335,230$ & $50,399,684$ & $1,053,358,110$ & 0.119 \\
\hline 1984 & $33,308,870$ & $35,716,379$ & $911,686,265$ & 0.091 \\
\hline 1985 & $31,483,884$ & $49,594,938$ & $926,905,946$ & 0.136 \\
\hline 1986 & $27,467,415$ & $61,105,003$ & $891,808,105$ & 0.169 \\
\hline 1987 & $32,197,900$ & $61,211,229$ & $929,380,379$ & 0.164 \\
\hline 1988 & $36,006,686$ & $92,388,631$ & $1,104,677,475$ & 0.234 \\
\hline 1989 & $43,539,346$ & $194,981,838$ & $1,400,406,829$ & 0.494 \\
\hline 1990 & $57,621,931$ & $178,036,313$ & $1,293,210,890$ & 0.438 \\
\hline 1991 & $65,049,557$ & $153,825,516$ & $1,707,095,165$ & 0.359 \\
\hline 1992 & $72,472,769$ & $155,503,414$ & $2,295,649,288$ & 0.382 \\
\hline 1993 & $77,798,480$ & $143,477,685$ & $3,463,930,183$ & 0.271 \\
\hline 1994 & $74,335,644$ & $175,099,128$ & $3,409,293,505$ & 0.258 \\
\hline 1995 & $78,609,637$ & $198,251,044$ & $3,495,438,521$ & 0.237 \\
\hline 1996 & $82,904,520$ & $228,537,095$ & $3,461,156,739$ & 0.216 \\
\hline 1997 & $88,941,501$ & $217,682,866$ & $3,861,951,390$ & 0.203 \\
\hline 1998 & $102,716,299$ & $244,355,682$ & $4,156,558,122$ & 0.183 \\
\hline 1999 & $109,990,998$ & $174,093,646$ & $4,137,711,690$ & 0.172 \\
\hline 2000 & $113,888,869$ & $106,183,647$ & $3,509,640,709$ & 0.109 \\
\hline 2001 & $131,576,004$ & $292,586,823$ & $4,476,364,817$ & 0.179 \\
\hline 2002 & $181,085,853$ & $300,621,071$ & $5,023,953,990$ & 0.153 \\
\hline 2003 & $196,084,835$ & $306,922,468$ & $7,772,750,866$ & 0.149 \\
\hline 2004 & $248,821,536$ & $568,111,683$ & $13,031,763,515$ & 0.233 \\
\hline 2005 & $443,537,476$ & $1,188,745,976$ & $26,667,097,118$ & 0.394 \\
\hline 2006 & $506,413,639$ & $954,625,862$ & $21,078,237,222$ & 0.209 \\
\hline 2007 & $609,409,310$ & $1,224,369,157$ & $29,214,202,327$ & 0.227 \\
\hline 2008 & $616,480,402$ & $1,470,900,200$ & $25,406,265,528$ & 0.226 \\
\hline 2009 & $576,881,469$ & $750,132,245$ & $22,526,919,428$ & 0.113 \\
\hline 2010 & $588,922,976$ & $811,847,384$ & $21,858,181,603$ & 0.116 \\
\hline 2011 & $842,732,877$ & $1,086,936,096$ & $19,272,757,327$ & 0.156 \\
\hline 2012 & $793,691,224$ & $1,057,613,228$ & $19,141,521,210$ & 0.132 \\
\hline 2013 & $711,757,101$ & $1,034,857,807$ & $18,233,491,417$ & 0.145 \\
\hline 2014 & $645,680,659$ & $1,000,148,733$ & $18,082,617,433$ & 0.162 \\
\hline 2015 & $708,030,488$ & $976,650,264$ & $17,984,673,970$ & 0.147 \\
\hline 2016 & $755,840,798$ & $829,157,424$ & $17,339,384,851$ & 12.220 \\
\hline
\end{tabular}

Source: https://www.ase.com.jo/ar

Major Financial Ratios for The ASE and Major Financial Indicators for the ASE. 
DIV

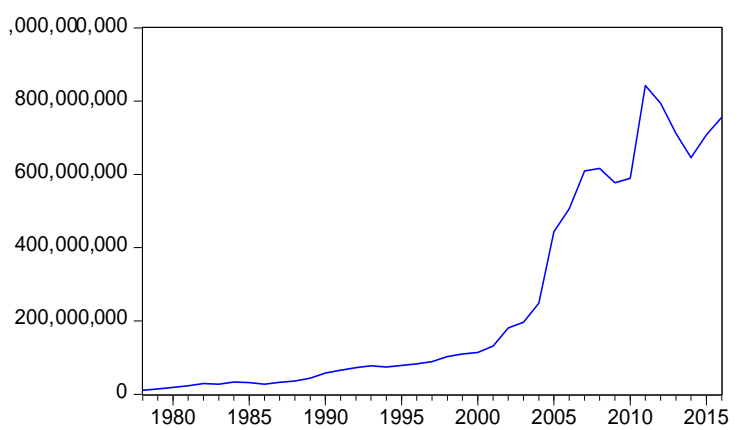

MC

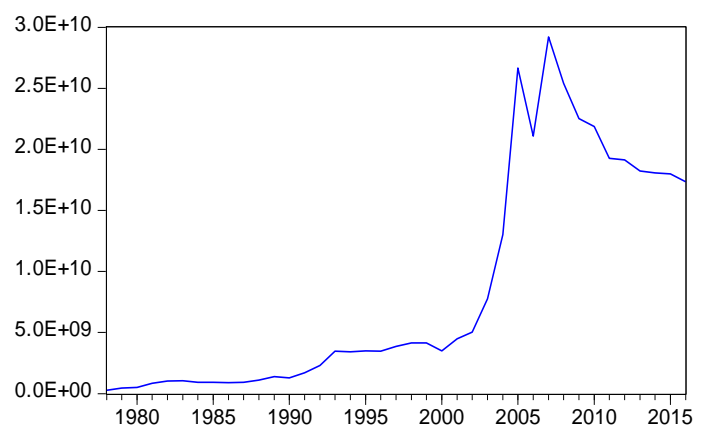

EPS

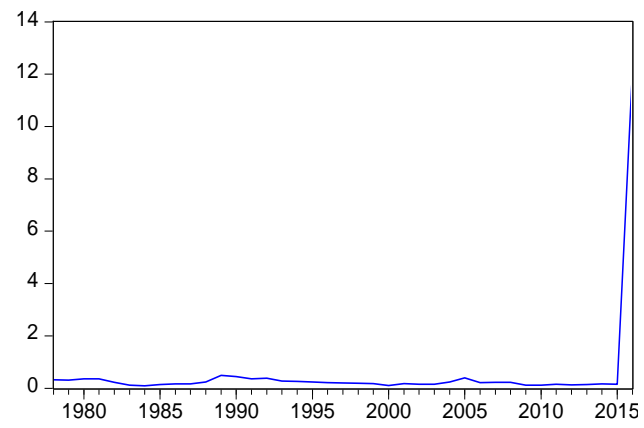

NI

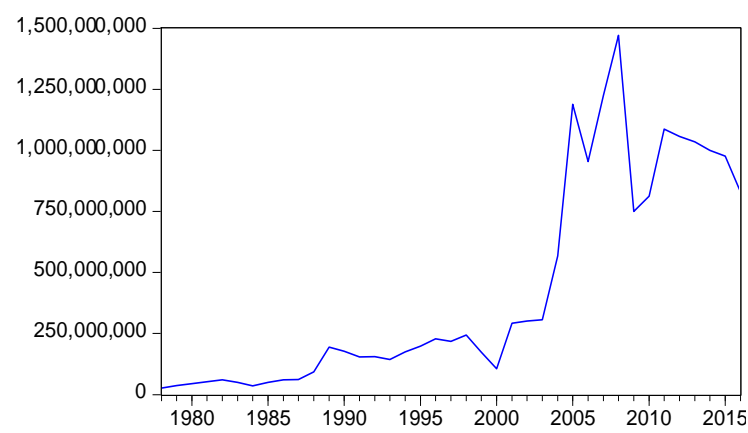

Figure 1. Graphs of study variables during the period (1978-2016)

Source: Prepared by the researcher according to the table data (I).

Div: Dividends.

EPS: Earning per shear.

MC: Market Capitalization.

NI: Net Income after Taxes.

Forms prepared by the researcher using the program E-views.

\section{Statistical Analysis}

Statistical tests used:

* Multiple liner regression.

* The ability of the model to predict.

* Stability degree.

* The causal relationship.

* T: test: Know the statistical significance of each variable.

* F change: to identify the significance of the model.

* R-Squared test: The explanatory power of the model is complete.

* D.W Test: Used to identify an autocorrelation problem, Where can be identified can autocorrelation problem of one-sided as follows.(Magdy, 1994).

Where:

- $\quad$ DL $>$ D.W:Indicates there is an autocorrelation problem from first- degree;

- DL: There is no an autocorrelation problem $>$ D.W;

- $\quad \mathrm{DU}<\mathrm{D} . \mathrm{W}<\mathrm{DL}$ : it cannot be judged; that there is an autocorrelation problem.

\subsection{Multiple Linear Regression}

The study will rely on multiple linear regression method, and use (E-views) program; to study the impact of the independent variables on market capitalization for stocks of listed companies in Amman Stock Exchange. 
Where the estimation was performed and the results were shown in appendix 1 . In order to improve the study results, the study will use the logarithm of the study data by estimating the following model:

$$
\log M C=a+B 1 \log D I V+B 2 \log N I+B 3 \log E P S+E l
$$

Where B1, B2, B3 are the regression parameters for independent variables, which can be through their signals determines, the direction of the relationship between the independent variables and the dependent variable. E: random error.

The model was evaluated as in appendix 2 , but $\mathrm{DL}=1.328>\mathrm{D} . \mathrm{W}=69$ at a significant level $5 \%$ and the number of observations 39 as in the D.W. The table indicates an autocorrelation problem from first- degree, and resolved through using AR(1) by (E-views) program. In appendix 3, the results can be summarized in Table 1 .

Table 2. Dependent variable: LOG(MC)

\begin{tabular}{cccc}
\hline Variable & Coefficient & t-Statistic & Prob. \\
\hline LOG(DIV) & 0.688192 & 5.718154 & 0.0000 \\
LOG(NI) & 0.288283 & 2.736856 & 0.0099 \\
LOG(EPS) & -0.023962 & -0.605201 & 0.5492 \\
C & 3.756493 & 2.145493 & 0.0394 \\
AR(1) & 0.715799 & 5.337391 & 0.0000 \\
\hline
\end{tabular}

D.W $=1.83$

Source: Prepared by the researcher using E-views according to the table data (I).

Of appendix No. $3 \mathrm{DL}=1.318<\mathrm{D} . \mathrm{W}=1.83$, at a significant level $5 \%$ and the number of observations 38 , as in the D.W tables, indicates there is no an autocorrelation problem.

Of the results, in Table 2, the existence of a positive relationship between statistical significance between the dividends and market capitalization. As well as the existence of a positive relationship of statistical significance between net income after taxes and market capitalization. However, there is no statistically significant relationship between the earning per shear and the market capitalization. This means that the investor is interested in the dividend of the share and the net profit after taxes, while, I investors do not care about the earnings per share.

Based on this, the model of the variables which have statistically significant will be recalculated. Where the model was estimated as in appendix (IV), But DL $=1.382>\mathrm{D} . \mathrm{W}=60$ at a significant level 5\%, and the number of observations (39). As D.W tables indicates that there is an autocorrelation problem from first- degree, where the problem will be solved though using AR (1) by (E-views) program. In appendix (V), the results can be summarized in Table 3.

$$
L O G(M C)=4.22+0.67 \log D I V+0.27 \log N I
$$

\begin{tabular}{|c|c|c|c|}
\hline Variable & Coefficient & t-Statistic & Prob. \\
\hline LOG(DIV) & 0.678906 & 5.356929 & 0.0000 \\
\hline LOG(NI) & 0.274865 & 2.710033 & 0.0105 \\
\hline $\mathrm{C}$ & 4.226510 & 2.280423 & 0.0290 \\
\hline $\mathrm{AR}(1)$ & 0.741845 & 5.921410 & 0.0000 \\
\hline \multicolumn{4}{|c|}{ 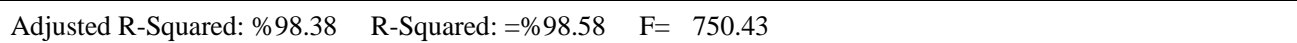 } \\
\hline $\mathrm{D}-\mathrm{W}=1.83$ & \multicolumn{3}{|c|}{ sig $\mathrm{F}$ change $=00.0$} \\
\hline
\end{tabular}

Table 3. Dependent variable: LOG (MC)

Source: prepared by the researcher using the program .E-views according to the table data (I).

Of appendix $5, \mathrm{DL}=1.373<\mathrm{D} . \mathrm{W}=1.83$, at a significant level $5 \%$ and the number of observations $=38$. As in D.W tables indicates there is no an autocorrelation problem.

The model shows the coefficient of determination (adjusted R-squared); which means that changes in the independent variables together explain about (98.38\%) of the changes in the dependent variable. Meanwhile, the value of the F-statistic reached 750.43, and the prob. significance level reached zero; meaning that the model is statistically significant. The Durbin-Watson (DW) coefficient reached (1.83); indicating that the model is appropriate and statistically significant, and it cannot be judged; that there is an autocorrelation problem or systematic error. 
Table 4. The correlation between the variables of the study

\begin{tabular}{ccccc}
\hline EPS & NI & MC & DIV & Variables \\
\hline 0.277495 & 0.935258 & 0.912706 & 1.000000 & DIV \\
0.144591 & 0.970559 & 1.000000 & 0.912706 & MC \\
0.142179 & 1.000000 & 0.970559 & 0.935258 & NI \\
1.000000 & 0.142179 & 0.144591 & 0.277495 & EPS \\
\hline
\end{tabular}

Source: prepared by the researcher using the program E-views according to the table data (I).

Table 4 shows the strength of the relationship between dividend, net income after taxes and market capitalization, while weak relationship between earnings per share and market capitalization; this means that investors do not care about the earnings per share, while they are concerned about the dividends and net income after taxes of listed companies in Amman Stock Exchange.

\subsection{Test the Ability of the Model to Predict}

The study can test the viability of the model and its forecasting ability for market capitalization by using (variance proportion), as shown in Figure 2.

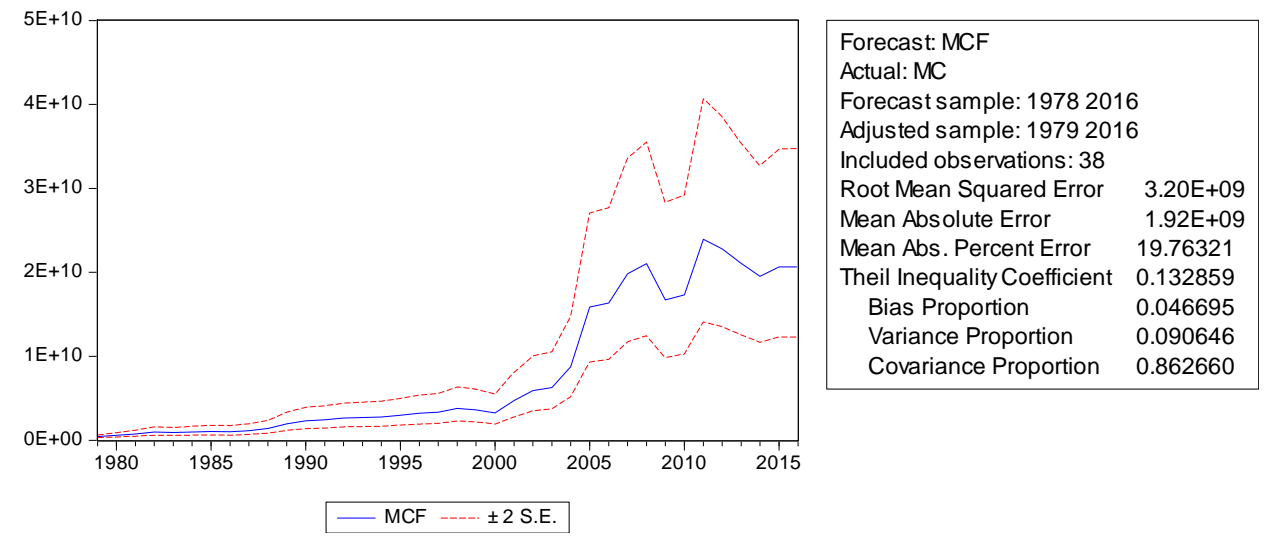

Figure 2. Testing the prediction ability of the model

Source: prepared by the researcher using the program E-views according to the table data (I).

The researcher conducted some standard tests to ensure the reliability, stability and viability (validity test) through tests, and the drawing shown below in figure 2 .

-Indicates (bias proportion) are (4.6\%);

-Variance proportion is equal to $(9 \%)$.

The value of the covariance proportion is equal to (86\%); which is an indication that the error in of the random errors in the model, also indicates that the predictive ability of the model for the market capitalization of Amman Stock Exchange is acceptable.

\subsection{Test of the Hypotheses}

The first hypothesis: There is a statistically significant positive relationship at the level of $\alpha \geq 0.05$ between the dividends profit and the market capitalization of companies listed in Amman Stock Exchange.

Table 3 shows, the value of the (DIV) is $67 \%$, which is a positive sign; which means that the relationship between the change in dividends and the change in market capitalization is positive, and that consistent with the theory which states that investors consider dividends to be a sign of the company's profit, the higher the dividends, the higher the price and vice versa. Also the theory of investors' preference for dividends as current income.

It also means increased dividends profit by $100 \%$; leading to increase the market capitalization of stocks of companies listed in Amman Stock Exchange by 67\%. The reality of the performance during the study period (1978-2016) shows a positive relationship. As evidenced by the market capitalization chart that has grown with the growth of dividends in Figure 1, this is also confirmed by the strong correlation between dividends and market capitalization in Table 2; this means that investors in the financial market are interested in dividends, which 
increase the demand for shares of companies and following the increase in the market capitalization of companies listed in Amman Stock Exchange.

According to the $\mathrm{T}-\mathrm{Test}$, this result is statistically significant at the $1 \%$. The confidence level for this variable is equal to 99\%; which indicates the acceptance of the hypothesis, which indicate that there is a statistically significant positive relationship at the level of $(\alpha \geq 0.05)$ between the dividends profit and the market value, while the null hypothesis is rejected.

The second hypothesis: There is a statistically significant positive relationship at the level of $\alpha \geq 0.05$ between the net income after taxes and the market capitalization of companies listed in Amman Stock Exchange.

Table 3 shows, the value of the (NI) is $27 \%$, which is a positive sign; which means that the relationship between the change in net income after taxes and the change in market capitalization is positive. This is consistent with the economic and financial literature; that emphasizes a positive relationship between the net income after taxes and the market capitalization.

It also means increasing the net income after taxes by (100\%), leading to increase the market capitalization of stocks of companies listed in Amman Stock Exchange by (27\%). As evidenced by the market capitalization chart that has grown with the growth of the net income after taxes in Figure 1, this is also confirmed by the strong correlation between the net income after taxes and market capitalization in Table 4. This means that investors in the financial market are interested in the net income after taxes, which increases the demand for shares of companies, as well as the market capitalization of companies listed on the Amman Stock Exchange.

According to the $\mathrm{T}-$ Test, this result is statistically significant at the (1\%). The confidence level for this variable is equal to (99\%) which indicates the acceptance of the hypothesis, which indicate that there is a statistically significant positive relationship at the level of $(\alpha \geq 0.05)$ between the net income after taxes and the market value, while the null hypothesis is rejected.

The third hypothesis: There is a statistically significant positive relationship at the level of $\alpha \geq 0.05$ between the earnings per share and the market capitalization of companies listed in Amman Stock Exchange.

Table 3 shows that there is no statistically significant relationship at the level of $\alpha \geq 0.05$ between the earnings per share and the market capitalization of companies listed in Amman Stock Exchange.

The reality of the performance during the study period (1978-2016), as can be seen from the graph of the market capitalization, grew with the decline in earnings per share in Figure 1. This is confirmed by the weak correlation between return on equity and market capitalization in Table 2 . This means that investors in the financial market do not care about earnings per share when they demand for shares; which does not impact the market capitalization of listed companies. Therefore, rejecting the hypothesis which indicates that there is a statistically significant-positive relationship at the level of $\alpha \geq 0.05$ between the earnings per share and the market capitalization of companies listed in Amman Stock Exchange. While the null hypothesis is accepted.

\subsection{Unit Root Test}

The results of unit root test are contained in the appendix 6 . The variables; market capitalization (mc), Dividends profit (DIV) and net income after taxes, stationary at 1 percent, 5 percent, and 10 percent level with first difference $\mathrm{d}(1)$; which is indicated by ADF results at all levels less than the critical values in negative direction.

The $\mathrm{ADF}$ value for $\mathrm{MC}$ is (-2.978503) and the critical values are (-2.630762) (-1.950394)and (-1.611202) at 1, 5, and 10 percent respectively.

The ADF value for (DIV) is (-4.774618) and the critical values are (-2.628961) (-1.950117-) and (1.611339) at 1 , 5 , and 10 percent respectively.

The ADF value for(NI) is (-2.705026) and the critical values are (-2.632688-) (1.950117) and (-1.611059) at 1,5, and 10 percent respectively. The null hypotheses of presence of unit root are both rejected at 1 percent level indicated by their probability value $0.01,0.05$ and 0.10 respectively, While EPS is unstable at any level.

\subsection{Causality Test}

The results of causality test are contained in the Appendix 7. The results revealed that there is unilateral causation between MC and DIV; this means increasing market capitalization caused by increased distributions, and this is due to corporate policy in Jordan.

The results revealed that there is unilateral causation between MC and NI; this means higher market capitalization reflects the company's successful financial management, also there is unilateral causation between NI and DIV. But there is not causation between MC and EPS, as there is not causation between DIV and EPS, 
also there is not causation between NI and EPS, and this confirms the result in the first model; that there is no impact of the EPS on the market value, while there is a statistically significant relationship between the market value, the dividends and the net income after taxes for companies listed in Amman Stock Exchange.

\section{Conclusion}

There is a statistically significant positive relationship at the level of $\alpha \geq 0.05$ between the dividends profit and the market capitalization of companies listed in Amman Stock Exchange. Also, there is a statistically significant positive relationship at the level of $\alpha \geq 0.05$ between the net income after taxes and the market capitalization of companies listed in Amman Stock Exchange; this means that investors in the financial market are interested in distributing dividends and net income after taxes in the demand for corporate shares. While there is no statistically significant at the level of $\alpha \geq 0.05$ between the earnings per share and the market capitalization of companies listed in Amman Stock Exchange; this means that investors in the financial market do not care about earnings per share when they demand for shares, which does not affect the market capitalization of listed companies.

The stability of all the variables is at the first difference at all levels, except the earring per shear is not stable at any level.

The results of unit root test of the variables; Market capitalization (mc), Dividends profit (DIV) and net income after taxes, stationary. The results of causality test is unilateral causation between MC, DIV and NI, but there is not causation between MC and EPS, as such there is no causation between DIV and EPS. Also there is no causation between NI and EPS.

When comparing the results of this study with previous studies. The results of this study focus on all companies listed on the Amman Stock Exchange so the generalization can be done, while previous studies have focused on specific sectors so that they cannot be generalized.

\section{Recommendations}

* The companies should consider the net income after taxes and the distribution of profits to the shareholders of the company; because of its direct impact on raising the market capitalization of the company's shares.

* The companies should take into account the investors' lack of interest in earnings per share, but attention to net income after taxes and dividends that affect $t$ he market capitalization of the company in Amman Stock Exchange.

* The companies should pay attention to raising the market value, which increases the capital gains of the shareholders and further distribution of profits for the circular relationship between them.

* To reformulate the dividends policy in companies; by taking into consideration investors' interest in the current profits distributed to the shareholders in the financial year.

* The launch of Amman Stock Exchange; using new tools to activate and stimulate the market finance.

\section{References}

Amalia, H. D., \& Isrochmani, M. (2014). The effect of net income after taxes margin, price to book value and debt to equity ratio to stock return in the Indo. Journal of Business and Management, 3(3), 305-315.

Amjad, I. Al-B. (2009). Examining the relationship between the distribution of profits and the market capitalization and book value of shares traded on the Palestine Securities Exchange. Master Thesis, Islamic University, Gaza, Faculty of Commerce, Accounting and Finance Department.

Ashamu, S. O., James, O., \& Abiola, S. O. B. (n. d.). Dividend policy as a strategic tool for funding public companies: Evidence from Nigeria. European Scientific Journal, 8(9).

Avdalović, S., \& Ivan, M. (2017). Impact of company performances on the stock price: an empirical analysis on select companies in Serbia. Economics of Agriculture, Original scientific paper.

Cristiano, A. B. F., Fernanda, M. P., \& Denis, L. A. (2013). Determinant Factors of Dividend Payments in Brazil. Retrieved from http://www.scielo.br/pdf/rcf/2015nahead/1519-7077-rcf-201512260.pdf

El Shorbagy, M. (1994). Econometrics between theory and practice (2nd ed., p. 197). Egyptian Lebanese House, Cairo.

Emeni, F. K., \& Ogbulu, O. M. (2015). The Effect of Dividend Policy on the market capitalization of Firms in the Financial Services Sector in Nigeria. Archives of Business Research, 3(4).

Hind, D. A. R. (2015). Test Effect Relationship between the Dividend and the Market Value of the Shares Using Some of the Tools of Financial Analysis - Applied Study of a Sample of Listed on the Iraq Stock Exchange 
Companies for the Period of 2010-2014. Muthanna Journal of Science Administration and Economics, 5(1).

Jalloh, M. A. (2017). Impact of Dividend Policy on Shareholders' Wealth: A Study of the Agriculture Industry in Nigeria. East Africa Research Papers in Business, Entrepreneurship and Management EARP-BEM No8, East Africa Collaborative Ph.D. Program in Economics and Management.

Kehinde, A., Uwalomwa, U., Olubukola, R. U., Osariemen, A., \& Sylvester, O. (2017). Dividend Policy and Share Price Valuation in Nigerian Banks. Euro Economica, 36(1).

Michelle, B. (2016). The Rise in Dividend Payments. Reserve bank of Australia. Retrieved from https://www.rba.gov.au/publications/bulletin/2016/mar/pdf/bu-0316-6.pdf

Pankaj, K. (2017). Impact of earning per share and price earnings ratio on market price of share: a study on auto sector in India. International Journal of Research - GRANTHAALAYAH.

Parviz, S., \& Abolghasem, O. (2012). Studying the effect of assets return rate on stock price of the companies in Tehran stock exchange. Business and Economic Horizons, 8(2), 12-22.

Rajesh, K. B., \& Sujit, K. S. (2018). Determinants of dividends among Indian firms-An empirical study. Cogent Economics \& Finance, 6.

Samuel, O. M., Duncan, M. N., \& Lilian, T. J. (2013). The Effect of Dividend Policy on Market Share Value in the Banking Industry; The Case of National Bank of Kenya. International Journal of Arts and Commerce, 2(2).

Shukairy, N. et al. (2016). Investment Management (1st ed.). Al-Massira House for Publishing, Distribution and Printing.

Stephen, A. et al. (2010). Fundamentals of corporate finance (9th ed.). New York: The McGraw-Hill.

Thomas, A. (2016). The Importance of Financial Ratios in Predicting Stock Price Trends: A Case Study in Emerging Markets. Finanse, Rynki Finansowe, Ubezpieczenianr, 13-26. Retrieved from http://www.wneiz.pl/nauka_wneiz/frfu/79-2016/FRFU-79-13.pdf

Vinay, K., \& Kavidayal, P. C. (2015). A Study of Dividend Policy And Its Effect on market capitalization of Shares of Selected Banks In India. IOSR Journal of Business and Management (IOSR-JBM), 17(1), 41-44.

Yuga, R. B. (2014). Determinants of Share Price of Nepalese Commercial Banks. Economic Journal of Development Issues, $17 \& 18(1-2)$.

\section{Appendix}

Appendix 1.

\begin{tabular}{|c|c|c|c|c|}
\hline \multicolumn{5}{|c|}{ Dependent Variable: MC } \\
\hline \multicolumn{5}{|c|}{ Method: Least Squares } \\
\hline \multicolumn{5}{|c|}{ Date: 07/14/18 Time: 17:00 } \\
\hline \multicolumn{5}{|c|}{ Sample: 19782016} \\
\hline \multicolumn{5}{|c|}{ Included observations: 39} \\
\hline Prob. & t-Statistic & Std. Error & Coefficient & Variable \\
\hline 0.7615 & 0.305908 & 4.142915 & 1.267352 & DIV \\
\hline 0.0000 & 7.637480 & 2.594504 & 19.81547 & $\mathrm{NI}$ \\
\hline 0.9816 & 0.023213 & $2.16 \mathrm{E}+08$ & 5019840. & EPS \\
\hline 0.6577 & -0.446947 & $5.26 \mathrm{E}+08$ & $-2.35 \mathrm{E}+08$ & $\mathrm{C}$ \\
\hline $8.52 \mathrm{E}+09$ & Mean dependent var & & 0.942184 & R-squared \\
\hline $9.23 \mathrm{E}+09$ & S.D. dependent var & & 0.937229 & Adjusted R-squared \\
\hline 46.05748 & Akaike info criterion & & $2.31 \mathrm{E}+09$ & S.E. of regression \\
\hline 46.22810 & Schwarz criterion & & $1.87 \mathrm{E}+20$ & Sum squared resid \\
\hline 46.11870 & Hannan-Quinn criter. & & -894.1208 & Log likelihood \\
\hline 1.711072 & Durbin-Watson stat & & 190.1245 & F-statistic \\
\hline & & & 0.000000 & Prob(F-statistic) \\
\hline
\end{tabular}


Appendix 2.

\begin{tabular}{|c|c|c|c|c|}
\hline & $\begin{array}{l}\text { Depe } \\
\text { Meth } \\
\text { Date: } \\
\text { Samp } \\
\text { Inclu }\end{array}$ & $\begin{array}{l}\text { ent Variable } \\
\text { : Least Squa } \\
7 / 14 / 18 \\
19782016 \\
\text { d observatio }\end{array}$ & $\begin{array}{l}\text { LOG(MC) } \\
\text { res } \\
\text { ime: } 17: 02 \\
\text { s: } 39\end{array}$ & \\
\hline Prob. & t-Statistic & Std. Error & Coefficient & Variable \\
\hline 0.0000 & 5.574075 & 0.119542 & 0.666337 & LOG(DIV) \\
\hline 0.0053 & 2.971850 & 0.130972 & 0.389229 & LOG(NI) \\
\hline 0.1120 & -1.630126 & 0.048492 & -0.079049 & LOG(EPS) \\
\hline 0.0022 & 3.297214 & 0.640587 & 2.112151 & $\mathrm{C}$ \\
\hline 22.09758 & \multicolumn{2}{|l|}{ Mean dependent var } & 0.974783 & R-squared \\
\hline 1.370980 & \multicolumn{2}{|l|}{ S.D. dependent var } & 0.972621 & Adjusted R-squared \\
\hline-0.032147 & \multicolumn{2}{|l|}{ Akaike info criterion } & 0.226849 & S.E. of regression \\
\hline 0.138475 & \multicolumn{2}{|l|}{ Schwarz criterion } & 1.801122 & Sum squared resid \\
\hline 0.029071 & \multicolumn{2}{|l|}{ Hannan-Quinn criter. } & 4.626859 & Log likelihood \\
\hline \multirow[t]{2}{*}{0.694952} & \multirow{2}{*}{\multicolumn{2}{|c|}{ Durbin-Watson stat }} & 450.9802 & F-statistic \\
\hline & & & 0.000000 & Prob(F-statistic) \\
\hline
\end{tabular}

Appendix 3.

\begin{tabular}{|c|c|c|c|c|}
\hline \multicolumn{5}{|c|}{ Dependent Variable: LOG(MC) } \\
\hline \multicolumn{5}{|c|}{ Method: Least Squares } \\
\hline \multicolumn{5}{|c|}{ Date: 07/14/18 Time: 17:03 } \\
\hline \multicolumn{5}{|c|}{ Sample (adjusted): 19792016} \\
\hline \multicolumn{5}{|c|}{ Included observations: 38 after adjustments } \\
\hline \multicolumn{5}{|c|}{ Convergence achieved after 7 iterations } \\
\hline Prob. & t-Statistic & Std. Error & Coefficient & Variable \\
\hline 0.0000 & 5.718154 & 0.120352 & 0.688192 & LOG(DIV) \\
\hline 0.0099 & 2.736856 & 0.105334 & 0.288283 & LOG(NI) \\
\hline 0.5492 & -0.605201 & 0.039593 & -0.023962 & LOG(EPS) \\
\hline 0.0394 & 2.145493 & 1.750877 & 3.756493 & $\mathrm{C}$ \\
\hline 0.0000 & 5.337391 & 0.134110 & 0.715799 & $\operatorname{AR}(1)$ \\
\hline 22.16667 & \multicolumn{2}{|l|}{ Mean dependent var } & 0.985287 & R-squared \\
\hline 1.318771 & \multicolumn{2}{|l|}{ S.D. dependent var } & 0.983504 & Adjusted R-squared \\
\hline-0.591290 & \multicolumn{2}{|l|}{ Akaike info criterion } & 0.169378 & S.E. of regression \\
\hline-0.375818 & \multicolumn{2}{|l|}{ Schwarz criterion } & 0.946732 & Sum squared resid \\
\hline-0.514627 & \multicolumn{2}{|l|}{ Hannan-Quinn criter. } & 16.23451 & Log likelihood \\
\hline \multirow[t]{3}{*}{1.834942} & \multirow{2}{*}{\multicolumn{2}{|c|}{ Durbin-Watson stat }} & 552.4972 & F-statistic \\
\hline & & & 0.000000 & Prob(F-statistic) \\
\hline & \multicolumn{3}{|c|}{.72} & Inverted AR Roots \\
\hline
\end{tabular}

Appendix 4.

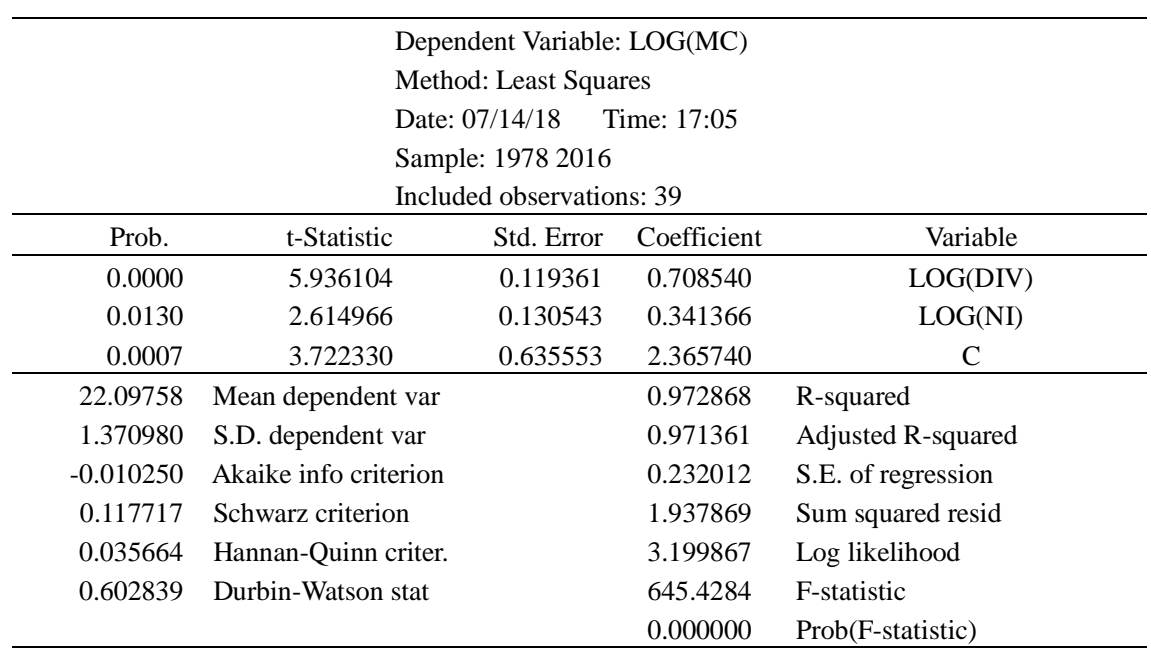


Appendix 5.

\begin{tabular}{|c|c|c|c|c|}
\hline \multicolumn{5}{|c|}{ Dependent Variable: LOG(MC) } \\
\hline \multicolumn{5}{|c|}{ Method: Least Squares } \\
\hline \multicolumn{5}{|c|}{ Date: 07/14/18 Time: 17:06 } \\
\hline \multicolumn{5}{|c|}{ Sample (adjusted): 19792016} \\
\hline \multicolumn{5}{|c|}{ Included observations: 38 after adjustments } \\
\hline \multicolumn{5}{|c|}{ Convergence achieved after 7 iterations } \\
\hline Prob. & $\mathrm{t}-$ Statistic & Std. Error & Coefficient & Variable \\
\hline 0.0000 & 5.356929 & 0.126734 & 0.678906 & LOG(DIV) \\
\hline 0.0105 & 2.710033 & 0.101425 & 0.274865 & LOG(NI) \\
\hline 0.0290 & 2.280423 & 1.853388 & 4.226510 & $\mathrm{C}$ \\
\hline 0.0000 & 5.921410 & 0.125282 & 0.741845 & $\mathrm{AR}(1)$ \\
\hline 22.16667 & \multicolumn{2}{|l|}{ Mean dependent var } & 0.985122 & R-squared \\
\hline 1.318771 & \multicolumn{2}{|l|}{ S.D. dependent var } & 0.983810 & Adjusted R-squared \\
\hline-0.632762 & \multicolumn{2}{|l|}{ Akaike info criterion } & 0.167802 & S.E. of regression \\
\hline-0.460385 & \multicolumn{2}{|l|}{ Schwarz criterion } & 0.957357 & Sum squared resid \\
\hline-0.571431 & \multicolumn{2}{|l|}{ Hannan-Quinn criter. } & 16.02248 & Log likelihood \\
\hline \multirow[t]{3}{*}{1.831915} & \multirow{2}{*}{\multicolumn{2}{|c|}{ Durbin-Watson stat }} & 750.4374 & F-statistic \\
\hline & & & 0.000000 & Prob(F-statistic) \\
\hline & \multicolumn{3}{|c|}{.74} & Inverted AR Roots \\
\hline
\end{tabular}

Appendix 6.

Null Hypothesis: D(NI) has a unit root

$$
\text { Exogenous: None }
$$

Lag Length: 2 (Automatic - based on SIC, maxlag=3)

\begin{tabular}{|c|c|c|c|c|}
\hline Prob.* & $\mathrm{t}$-Statistic & & & \\
\hline \multirow[t]{11}{*}{0.0083} & -2.705026 & \multicolumn{3}{|c|}{ Augmented Dickey-Fuller test statistic } \\
\hline & -2.632688 & & $1 \%$ level & \multirow[t]{3}{*}{ Test critical values: } \\
\hline & -1.950687 & & $5 \%$ level & \\
\hline & -1.611059 & & $10 \%$ level & \\
\hline & \multicolumn{4}{|c|}{ *MacKinnon (1996) one-sided p-values. } \\
\hline & \multicolumn{4}{|c|}{ Augmented Dickey-Fuller Test Equation } \\
\hline & \multicolumn{4}{|c|}{ Dependent Variable: D(NI,2) } \\
\hline & \multicolumn{4}{|c|}{ Method: Least Squares } \\
\hline & \multicolumn{4}{|c|}{ Date: 07/09/18 Time: $14: 13$} \\
\hline & \multicolumn{4}{|c|}{ Sample (adjusted): 19822016} \\
\hline & \multicolumn{4}{|c|}{ ncluded observations: 35 after adjustments } \\
\hline Prob. & \multicolumn{2}{|c|}{ t-Statistic } & Coefficient & Variable \\
\hline 0.0109 & \multicolumn{2}{|c|}{-2.705026} & -0.937121 & $\mathrm{D}(\mathrm{NI}(-1))$ \\
\hline 0.5708 & \multicolumn{2}{|c|}{-0.572776} & -0.146172 & $\mathrm{D}(\mathrm{NI}(-1), 2)$ \\
\hline 0.0366 & \multicolumn{2}{|c|}{-2.182130} & -0.364167 & $\mathrm{D}(\mathrm{NI}(-2), 2)$ \\
\hline-4452154 & \multicolumn{2}{|c|}{ Mean dependent var } & 0.655671 & R-squared \\
\hline $2.98 \mathrm{E}+08$ & \multicolumn{2}{|c|}{ S.D. dependent var } & 0.634150 & Adjusted R-squared \\
\hline 40.93757 & \multicolumn{2}{|c|}{ Akaike info criterion } & $1.80 \mathrm{E}+08$ & S.E. of regression \\
\hline 41.07089 & \multicolumn{2}{|c|}{ Schwarz criterion } & $1.04 \mathrm{E}+18$ & Sum squared resid \\
\hline \multirow[t]{2}{*}{40.98359} & \multirow{2}{*}{\multicolumn{2}{|c|}{ Hannan-Quinn criter. }} & -713.4075 & Log likelihood \\
\hline & & & 1.848672 & Durbin-Watson stat \\
\hline
\end{tabular}


Null Hypothesis: D(DIV) has a unit root

Exogenous: None

Lag Length: 0 (Automatic - based on SIC, maxlag=3)

\begin{tabular}{|c|c|c|c|c|}
\hline Prob.* & t-Statistic & & & \\
\hline 0.0000 & -4.774618 & \multicolumn{3}{|c|}{ Augmented Dickey-Fuller test statistic } \\
\hline \multicolumn{3}{|c|}{-2.628961} & $1 \%$ level & Test critical values: \\
\hline \multicolumn{3}{|c|}{-1.950117} & $5 \%$ level & \\
\hline \multicolumn{3}{|c|}{-1.611339} & $10 \%$ level & \\
\hline \multicolumn{5}{|c|}{ *MacKinnon (1996) one-sided p-values. } \\
\hline \multicolumn{5}{|c|}{ Augmented Dickey-Fuller Test Equation } \\
\hline \multicolumn{5}{|c|}{ Dependent Variable: D(DIV,2) } \\
\hline \multicolumn{5}{|c|}{ Method: Least Squares } \\
\hline \multicolumn{5}{|c|}{ Date: 07/09/18 Time: $14: 15$} \\
\hline \multicolumn{5}{|c|}{ Sample (adjusted): 19802016} \\
\hline \multicolumn{5}{|c|}{ Included observations: 37 after adjustments } \\
\hline Prob. & \multicolumn{2}{|c|}{$\mathrm{t}$-Statistic } & Coefficient & Variable \\
\hline 0.0000 & \multicolumn{2}{|c|}{-4.774618} & -0.783317 & $\mathrm{D}(\mathrm{DIV}(-1))$ \\
\hline 1181920. & \multicolumn{2}{|c|}{ Mean dependent var } & 0.387583 & R-squared \\
\hline 79199933 & \multicolumn{2}{|c|}{ S.D. dependent var } & 0.387583 & Adjusted R-squared \\
\hline 38.74916 & \multicolumn{2}{|c|}{ Akaike info criterion } & 61979530 & S.E. of regression \\
\hline 38.79270 & \multicolumn{2}{|c|}{ Schwarz criterion } & $1.38 \mathrm{E}+17$ & Sum squared resid \\
\hline \multirow[t]{2}{*}{38.76451} & \multirow{2}{*}{\multicolumn{2}{|c|}{ Hannan-Quinn criter. }} & -715.8595 & Log likelihood \\
\hline & & & 1.941159 & Durbin-Watson stat \\
\hline
\end{tabular}

Null Hypothesis: D(MC) has a unit root

Exogenous: None

Lag Length: 1 (Automatic - based on SIC, maxlag=3)

\begin{tabular}{ccc}
\hline Prob.* $^{*}$ & $\mathrm{t}$-Statistic & \\
\hline 0.0040 & -2.978503 & Augmented Dickey-Fuller test statistic \\
& -2.630762 & $1 \%$ level $\quad$ Test critical values: \\
& -1.950394 & $5 \%$ level \\
& -1.611202 & $10 \%$ level \\
\hline
\end{tabular}

*MacKinnon (1996) one-sided p-values.

Augmented Dickey-Fuller Test Equation

Dependent Variable: D(MC,2)

Method: Least Squares

Date: 07/09/18 Time: 14:16

Sample (adjusted): 19812016

Included observations: 36 after adjustments

\begin{tabular}{ccccl}
\hline Prob. & t-Statistic & Std. Error & Coefficient & \multicolumn{1}{c}{ Variable } \\
\hline 0.0053 & -2.978503 & 0.240498 & -0.716324 & \multicolumn{1}{c}{$\mathrm{D}(\mathrm{MC}(-1))$} \\
0.0262 & -2.323838 & 0.159407 & -0.370437 & \multicolumn{1}{c}{$\mathrm{D}(\mathrm{MC}(-1), 2)$} \\
\hline-19125669 & Mean dependent var & & 0.627773 & R-squared \\
$4.80 \mathrm{E}+09$ & S.D. dependent var & & 0.616826 & Adjusted R-squared \\
46.51430 & Akaike info criterion & & $2.97 \mathrm{E}+09$ & S.E. of regression \\
46.60228 & Schwarz criterion & & $3.00 \mathrm{E}+20$ & Sum squared resid \\
46.54501 & Hannan-Quinn criter. & & -835.2575 & Log likelihood \\
& & & 2.094378 & Durbin-Watson stat \\
\hline
\end{tabular}


Null Hypothesis: D(EPS) has a unit root

Exogenous: None

Lag Length: 0 (Automatic - based on SIC, maxlag=3)

\begin{tabular}{|c|c|c|c|c|}
\hline Prob.* & t-Statistic & & & \\
\hline \multirow[t]{11}{*}{0.5212} & -0.429531 & \multicolumn{3}{|c|}{ Augmented Dickey-Fuller test statistic } \\
\hline & \multicolumn{2}{|l|}{-2.628961} & $1 \%$ level & Test critical values: \\
\hline & \multicolumn{2}{|l|}{-1.950117} & $5 \%$ level & \\
\hline & \multicolumn{2}{|l|}{-1.611339} & $10 \%$ level & \\
\hline & \multicolumn{4}{|c|}{ *MacKinnon (1996) one-sided p-values. } \\
\hline & \multicolumn{4}{|c|}{ Augmented Dickey-Fuller Test Equation } \\
\hline & & \multicolumn{3}{|c|}{ Dependent Variable: D(EPS,2) } \\
\hline & & \multicolumn{3}{|c|}{ Method: Least Squares } \\
\hline & & \multicolumn{3}{|c|}{ Date: 09/01/18 Time: 08:44 } \\
\hline & & \multicolumn{3}{|c|}{ Sample (adjusted): 19802016} \\
\hline & \multicolumn{4}{|c|}{ Included observations: 37 after adjustments } \\
\hline Prob. & \multicolumn{2}{|c|}{ t-Statistic } & Coefficient & Variable \\
\hline 0.6701 & \multicolumn{2}{|c|}{-0.429531} & -1.820252 & $\mathrm{D}(\mathrm{EPS}(-1))$ \\
\hline 0.326541 & \multicolumn{2}{|c|}{ Mean dependent var } & -0.022420 & R-squared \\
\hline 1.990485 & \multicolumn{2}{|c|}{ S.D. dependent var } & -0.022420 & Adjusted R-squared \\
\hline 4.263462 & \multicolumn{2}{|c|}{ Akaike info criterion } & 2.012675 & S.E. of regression \\
\hline 4.307000 & \multicolumn{2}{|c|}{ Schwarz criterion } & 145.8311 & Sum squared resid \\
\hline \multirow[t]{2}{*}{4.278811} & \multirow{2}{*}{\multicolumn{2}{|c|}{ Hannan-Quinn criter. }} & -77.87405 & Log likelihood \\
\hline & & & 1.000726 & Durbin-Watson stat \\
\hline
\end{tabular}

Appendix 7.

\begin{tabular}{|c|c|c|c|}
\hline \multicolumn{4}{|c|}{ Pairwise Granger Causality Tests } \\
\hline Date: $07 / 09 / 18$ & Time: $21: 12$ & & \\
\hline \multicolumn{4}{|c|}{ Sample: 19782016} \\
\hline \multicolumn{4}{|c|}{ Lags: 3} \\
\hline Prob. & F-Statistic & Obs & Null Hypothesis: \\
\hline 0.9945 & 0.02498 & 36 & EPS does not Granger Cause DIV \\
\hline 0.1052 & 2.23589 & \multicolumn{2}{|c|}{ DIV does not Granger Cause EPS } \\
\hline 0.0442 & 3.05257 & 36 & MC does not Granger Cause DIV \\
\hline 0.9151 & 0.17096 & \multicolumn{2}{|c|}{ DIV does not Granger Cause MC } \\
\hline 0.0315 & 3.37884 & 36 & NI does not Granger Cause DIV \\
\hline 0.1753 & 1.76780 & \multicolumn{2}{|c|}{ DIV does not Granger Cause NI } \\
\hline 0.8640 & 0.24533 & 36 & MC does not Granger Cause EPS \\
\hline 0.6923 & 0.48943 & \multicolumn{2}{|c|}{ EPS does not Granger Cause MC } \\
\hline 0.5950 & 0.64073 & 36 & NI does not Granger Cause EPS \\
\hline 0.9633 & 0.09304 & \multicolumn{2}{|c|}{ EPS does not Granger Cause NI } \\
\hline 0.5793 & 0.66681 & 36 & NI does not Granger Cause MC \\
\hline 0.0336 & 3.31786 & \multicolumn{2}{|c|}{ MC does not Granger Cause NI } \\
\hline
\end{tabular}

\section{Copyrights}

Copyright for this article is retained by the author(s), with first publication rights granted to the journal.

This is an open-access article distributed under the terms and conditions of the Creative Commons Attribution license (http://creativecommons.org/licenses/by/4.0/). 